\title{
Effect of Balanced Fertilization and Fertilizer Levels on Navel Orange Yield and Fruit Quality
}

\author{
Zaghloul, A.E. ${ }^{1}$ and Knany, R.E. ${ }^{2}$
}

\begin{abstract}
A field experiment was conducted during two successive seasons of $2007 / 2008$ and $2008 / 2009$ on navel orange mature trees at Metobas district, Kafr El-Sheikh governorate, Egypt, to assess effect of the balanced fertilization and fertilization levels on navel orange yield and fruit quality. Four fertilizer treatments of: 1- complete fertilizer (balanced), 2- fertilizer without $\mathrm{Mg}$, 3- Fertilizer without micronutrients, and 4-fertilizer without $K$ with three fertilizer levels $L_{1}, L_{2}$ and $L 3$ were used compared to the farmer treatment. The obtained results can be summarized as follows:
\end{abstract}

-The balanced fertilizer (complete) had the highest fruit set (7.8 and $8.1 \%)$, lowest pre-harvest fruit drop (7.9 and 7.8\%), highest fruit number/tree (405.1 and 391.9), highest fruit yield/tree $(86.0$ and $93.1 \mathrm{~kg} /$ tree $)$, highest SSC\% (11.9 and 12.3\%) and highest VC (58.2 and 58.4 $\mathrm{mg} / 100 \mathrm{ml}$ juice) in the first and second seasons, respectively.

-Balanced fertilizer increased reducing sugar rates by 22.8 and $41.9 \%$, non-reducing sugar by 44 and $16.7 \%$ and total sugars by 34.6 and $31.1 \%$ over the farmer treatment in the first and second seasons, respectively.

-Balanced fertilizer increased the rates of chlorophyll A, B and total chlorophyll compared to the farmer treatment. The increase rates in total chlorophyll were 45.8 and $44.0 \%$ over the farmer treatment in the first and second seasons, respectively.

-Farmer treatment had the lowest fruit set (5.4 and 5.7\%), fruit yield (66.8 and $70.2 \mathrm{~kg} /$ tree), highest pre-harvest fruit drop (12.9 and $12.4 \%)$, lowest acidity values 0.92 and $0.91 \%$, VC $(52.3$ and $52.7 \mathrm{mg} / 100 \mathrm{ml}$ juice), reducing sugars (3.5 and $3.1 \%)$, non-reducing sugars (2.5 and 3.0\%), total sugars $(5.9$ and $6.1 \%)$, chlorophyll A, B and total chlorophyll, in the first and second seasons, respectively.

-Fertilizer without $\mathrm{Mg}$, micronutrients and potassium gave a high values than the farmer treatment for each fruit set $(\%)$, fruit number/tree, fruit yield (kg/tree), acidity $(\%)$, VC, reducing, non-reducing, total sugars and total chlorophyll. That values were less than the complete fertilizer during the first and second seasons, respectively.

-The increase value rates compared with the farmer treatment were $(29.2$ and $28.1 \%) \&(36.5$ and $28.1 \%)$ $\&(12.5$ and $14.0 \%)$ in fruit set, $(9.1$ and $25.5 \%) \&$ $(19.1$ and $15.9 \%) \&(21.9$ and $0.0 \%)$ in yield $\mathrm{kg} /$ tree, (6.5 and 6.5\%) \& $(3.3$ and $2.2 \%) \&(2.2$ and $2.2 \%)$ in acidity $(2.9$ and $3.2 \%) \&(7.3$ and $6.8 \%) \&(7.5$ and $5.1 \%)$ in VC, $(2.9$ and $12.9 \%) \&(17.1$ and $38.7 \%) \&$ $(5.7$ and $16.1 \%)$ in reducing sugars, $(10.2$ and $3.3 \%) \&$ $(22.0-$ and $21.3 \%) \&(17.8$ and $9.8 \%)$ in total sugars, (39.5 and $28.6 \%) \&(11.3$ and $17.1 \%) \&(38.8$ and $37.2 \%$ ) in total chlorophyll during the two seasons for the three treatments, respectively.

-Farmer treatment showed the highest values for preharvest fruit drop (12.9 and 12.4\%) and SSC\% (11.9 and $11.4 \%$ ) compared with the four treatments during the first and seconds seasons, respectively.

\section{INTRODUCTION}

Citrus is an important fruit crop in more than 135 countries with production about 102.64 million tons annually world wide. It has a great nutritional role in our daily food requirements, being a rich source of vitamin C. Citrus trees require large quantities of mineral nutrients to attain adequate growth and yield, and requirements for some of the nutrients vary with soil fertility and type.

The Egyptian soils varied with respect to their texture from sandy to heavy clay soils. Average value of total soluble $\mathrm{N}$ is very low and the organic matter is also low, the soil reaction was slightly alkaline, the available $\mathrm{P}$ values are moderate, however, the available $\mathrm{K}$ ranged between low and high.

Plant nutrient management for citrus can influence flowering, fruit set, fruit size and the amount of vegetative growth and other plant characteristics. By carefully choosing the components of fertilizer program, the grower can nudge a crop toward earlier, heavier fruit set (Muhammad Yaseen and Manzoor Ahmad, 2010). Fruit yield of citrus is largely dependent on nitrogen fertilization, which plays an important role in tree nutrition.

Sanchez et al. (2002) in that one year study on 8 years old lemon trees noted that, just $681 \mathrm{~g} \mathrm{~N}$ per tree was sufficient for maximum yield.

Increasing nitrogen fertilization from $227 \mathrm{~g} \mathrm{~N}$ per tree to 1135 annually on sweet orange significantly increased fruit yield represents 20\% (Glenn, 2009).

Beanland et al. (2003) reported that, nutrient deficiency or imbalances may alter primary and

${ }^{1}$ Fruit Handling Dept., Hort. Res. inst., ARC, Giza, Egypt.

${ }^{2}$ Soils, Water and Environment Res. Inst., ARC, Giza, Egypt.

Received February 22, 2012, Accepted March29, 2012 
secondary metabolism, and thus faster growth of herbivores.

Phosphorus is the second majour essential macroelements for plants. It plays a key role of energy storage and transferring. Its availability changes quickly after fertilization due to high soil reaction. Earlier research work has demonstrated that, limited phosphorus availability of low fertility soils impairs citrus production (Quaggio et al., 2002). Dircenmattos et al. (2010) demonstrated that, greater growth of citrus plants corresponded to greater root development as evaluated by root growth rate and architecture. These parameters varied according to phosphorus availability in soil. Excessive phosphorus can adversely affect citrus growth and development, especially fruit quality. High phosphorus fertilization has lowered juice soluble solids concentration and caused delayed external color development and re-greening oranges (Thomas, 2001).

Potassium plays a critical role in citrus trees and it affects many phenomena, both visible and invisible. The requirement for potassium in trees is next to that for nitrogen and ranges from 0.5 to $2.0 \%$ of dry matter. According to various sources, one ton of oranges exports an average of $2.5 \mathrm{~kg} \mathrm{~K}_{2} \mathrm{O}$ corresponding to 125 $250 \mathrm{~kg} / \mathrm{ha}$ according to the yield potential (Erner et al., 2002). Malavolta (1992) reported that, potassium fertilization increased orange fruit production up to leaf potassium content of $1.5-1.7 \%$. Potassium has dominant effects on external and internal fruit qualities, including yield, colour, size, acidity and roughness. Excessively high $\mathrm{K}$ levels result in large fruit with coarse, thick peel and poor colour. Moreover, early and intensive regreening will occur (Erner et al., 2002). Du-Plesis and Koen (1988) found that a maximum yield at the high $\mathrm{N}: \mathrm{K}$ ratio of 2.8 with the $\mathrm{N}$ and $\mathrm{K}$ contents exceeding 2.1 and $0.8 \%$, respectively.

Magnesium is one of the essential secondary macronutrients. It is taken up by plants as $\mathrm{Mg}$ ions. It plays a key role in the photosynthetic process, being an important constituent of chlorophyll, the green pigment in leaves and stems. The presence of other positively charged ions in the soil or their application in fertilizers i.e., calcium, potassium, sodium and ammonium may depress plant uptake of magnesium. So, magnesium fertilizer must applied for balanced fertilization.

Iron, zinc, manganese, copper, boron and molybdenum are essential micronutrients for plants. Under the Egyptian conditions all the micronutrients unavailable except molybdenum. Embelton et al. (1973) reported that, zinc applied to alkaline soil is usually adsorbed or precipitated on the surface and does not move readily to the root zone. Further citrus is deep rooted crop, so micronutrient application to soil may be of little value. Foliar application of $\mathrm{Zn}$ and $\mathrm{Mn}$ alone or in combination with each other significantly increased the fruit yield of sweet oranges compared with the control treatment. The maximum fruit yield of 123.3 $\mathrm{kg} /$ tree was obtained from the treatment receiving $\mathrm{Zn}+$ Mn (Tariq et al., 2007).

Muhammad et al. (2010) found that the foliar application of $\mathrm{Zn}$ and $\mathrm{B}$ significantly influenced, fruit yield/tree, \% dieback, \% chlorosis and \% rosette/plant. The maximum fruit yield/plant was obtained when high concentration of $\mathrm{Zn}(1 \% \mathrm{Zn})$ with low concentration of B $(0.02 \%$ B).

The objectives of the present study is to investigate the role of nitrogen and phosphorus fertilization levels, and potassium, magnesium and micronutrients presence and levels as a balanced fertilization on navel orange yield and quality under north Delta Egyptian soils.

\section{MATERIALS AND METHODS}

A field experiment was conducted at Motobas district, Kafr El-Sheikh governorate, Egypt. The latitude and longitude of the experiment field are $31^{\circ} 27 \mathrm{~N}$ and $31^{\circ} 32 \mathrm{E}$ during two successive seasons of $2007 / 2008$ and $2008 / 2009$, on permanent mature navel orange trees to assess effect of the balanced fertilization on the yield and fruit quality. Randomized complete block design layout was used with four replicates, where one similar tree is one plot. Composite soil sample was collected from the experimental field before conducting the treatments, to investigate some soil physical and chemical as well as nutritional properties of the experimental field according to Black et al. (1965). Thirteen fertilization treatment were used as follows:

1. $495 \mathrm{~g} \mathrm{~N}+101.5 \mathrm{~g} \mathrm{P}\left(232.5 \mathrm{~g} \mathrm{P}_{2} \mathrm{O}_{5}\right) /$ tree/year (farmer treatment).

2. $495 \mathrm{~g} \mathrm{~N}+101.5 \mathrm{~g} \mathrm{P}+400 \mathrm{~g} \mathrm{~K}\left(480 \mathrm{~g} \mathrm{~K}_{2} \mathrm{O}\right)+50 \mathrm{~g}$ $\mathrm{S}+2.5 \mathrm{~g} \mathrm{Mg}+$ micronutrients $\left(\mathrm{L}_{1}\right)$.

3. 990 g N +203 g P +800 g K +50 g S +5 g Mg + micronutrients/tree/year $\left(\mathrm{L}_{2}\right)$.

4. $1485 \mathrm{~g} \mathrm{~N}+304.5 \mathrm{~g} \mathrm{P}+1200 \mathrm{~g} \mathrm{~K}+50 \mathrm{~g} \mathrm{~S}+7.5 \mathrm{~g}$ $\mathrm{Mg}+$ micronutrients/tree/year $\left(\mathrm{L}_{3}\right)$.

5. $495 \mathrm{~g} \mathrm{~N}+101.5 \mathrm{~g} \mathrm{P}+400 \mathrm{~g} \mathrm{~K}+50 \mathrm{~g} \mathrm{~S}+0 \mathrm{Mg}+$ Micronutrient/tree/year $\left(\mathrm{L}_{1}\right.$ without $\left.\mathrm{Mg}\right)$.

6. $990 \mathrm{~g} \mathrm{~N}+203 \mathrm{~g} \mathrm{P}+800 \mathrm{~g} \mathrm{~K}+50 \mathrm{~g} \mathrm{~S}+0 \mathrm{Mg}+$ micronutrients/tree/year $\left(\mathrm{L}_{2}\right.$ without $\left.\mathrm{Mg}\right)$

7. $1485 \mathrm{~g} \mathrm{~N}+304.5 \mathrm{~g} \mathrm{P}+1200 \mathrm{~g} \mathrm{~K}+50 \mathrm{~g} \mathrm{~S}+0 \mathrm{Mg}+$ micronutrients/tree/year (L3 without $\mathrm{Mg}$ ).

8. $495 \mathrm{~g} \mathrm{~N}+101.5 \mathrm{~g} \mathrm{P}+400 \mathrm{~g} \mathrm{~K}+50 \mathrm{~g} \mathrm{~S}+2.5 \mathrm{~g} \mathrm{Mg}$ +0 micro/tree/year $\left(\mathrm{L}_{1}\right.$ without micronutrients).

9. $990 \mathrm{~g} \mathrm{~N}+203 \mathrm{~g} \mathrm{P}+800 \mathrm{~g} \mathrm{~K}+50 \mathrm{~g} \mathrm{~S}+5 \mathrm{~g} \mathrm{Mg}+0$ Micronutrients/tree/year ( $\mathrm{L}_{2}$ without micronutrients). 
10.1485 g N $+304.5 \mathrm{~g} \mathrm{P}+1200 \mathrm{~g} \mathrm{~K}+50 \mathrm{~g} \mathrm{~S}+7.5 \mathrm{~g}$ $\mathrm{Mg}+0$ micronutrients/tree/year $\left(\mathrm{L}_{3}\right.$ without micronutrients).

$11.495 \mathrm{~g} \mathrm{~N}+101.5 \mathrm{~g} \mathrm{P}+0 \mathrm{~K}+50 \mathrm{~g} \mathrm{~S}+2.5 \mathrm{~g} \mathrm{Mg}+$ micronutrient/tree/year $\left(\mathrm{L}_{1}\right.$ without $\left.\mathrm{K}\right)$.

$12.990 \mathrm{~g} \mathrm{~N}+203 \mathrm{~g} \mathrm{P}+0 \mathrm{~K}+50 \mathrm{~g} \mathrm{~S}+5 \mathrm{~g} \mathrm{Mg}+$ micronutrient/tree/year $\left(\mathrm{L}_{2}\right.$ without $\left.\mathrm{K}\right)$.

13. $1485 \mathrm{~g} \mathrm{~N}+304.5 \mathrm{~g} \mathrm{P}+0 \mathrm{~K}+50 \mathrm{~g} \mathrm{~S}+7.5 \mathrm{~g} \mathrm{Mg}+$ micronutrient/tree/year $\left(\mathrm{L}_{3}\right.$ without $\left.\mathrm{K}\right)$.

Nitrogen was applied as ammonium nitrate $33 \% \mathrm{~N}$, phosphorus was applied as single super phosphate calcium $15.5 \% \mathrm{P}_{2} \mathrm{O}_{5}(6.77 \% \mathrm{P})$, potassium was applied as potassium sulphate $48 \% \mathrm{~K}_{2} \mathrm{O}(40 \% \mathrm{~K})$, magnesium was applied as magnesium sulphate $(8.9 \% \mathrm{Mg})$, sulphur was applied as sulphur metal and micronutrients were applied a mixture of $300,150,100,50$ and $50 \mathrm{mg} / \mathrm{kg}$ of the applied fertilizer from chelated $\mathrm{Fe}, \mathrm{Mn}, \mathrm{Zn}, \mathrm{Cu}$ and $\mathrm{B}$ as boric acid, respectively. Just mature leaves samples were collected from the different treated trees, chlorophyll A, B and total chlorophyll were determined according to Moran and Porath (1982).

Yield and fruit characters were determined i.e., fruit set $\%$, pre-harvest fruit drop $\%$, fruit weight (g), fruit number/tree and fruit yield $\mathrm{kg} /$ tree. Some fruit physical parameters and juice quality properties were determined i.e., acidity \%, vitamin $\mathrm{C} \mathrm{mg} / 100 \mathrm{ml}$ juice, reducing, non-reducing and total sugars $\%$ as well as $\mathrm{SSC} \%$ according to AOAC (1985).

\section{RESULTS AND DISCUSSIONS}

\section{The effect of balanced fertilizers on fruit physical parameters of navel orange:}

\subsection{Fruit set:}

Data presented in Table (2) showed that, balanced fertilizer had high significant effect on citrus fruit set $\%$. In the first season, the highest mean value of $7.8 \%$ was obtained with the complete fertilizer. On the other hand, the lowest value of fruit set $\%$ of $5.4 \%$ was recorded with the farmer treatment. The fertilizer without potassium had the less value of the fruit set $\%$ compared to the other three compounds fertilizers of $6.1 \%$. The sequence of fruit set $\%$ was complete fertilizer (7.8) > fertilizer without micronutrients (7.4)> fertilizer without $\mathrm{Mg}$ (7.0) > fertilizer without $\mathrm{K}(6.1)>$ farmer treatment (5.4). In the second season, the data had the same sequence,

where it was $8.1 \%, 7.3,7.3 \%, 6.5 \%$ and $5.7 \%$, respectively. In respect to the effect of fertilizer levels on citrus fruit set $\%$, the high level had the highest fruit set values of 7.2 and $7.4 \%$ in the first and second season, respectively. The interaction between the fertilizer content and the fertilizer levels on fruit set \% showed that the highest fruit set value of $8.45 \%$ was obtained with the high fertilizer level (L3) and the complete fertilizer in both seasons. These results showed that, imbalances fertilizers may be due to alter the plants metabolism. These results are agree with those obtained by El-Sabrout and Kassem (2002), Mostafa (2002) on Washington navel orange trees and Beanland et al. (2003).

\subsection{Pre-harvest fruit drop\%:}

Data presented in Table (2) showed that, farmer treatment recorded the highest pre-harvest fruit drop value of 12.94 and $12.35 \%$ in the first and second season, respectively. The sequence of pre-harvest fruit drop values in the first season was complete fertilizer $(7.9 \%)<$ fertilizer without $\mathrm{Mg}(8.4 \%)<$ fertilizer without micronutrient $(8.5 \%)<$ fertilizer without $\mathrm{K}$ $(10.9 \%)<$ the farmer treatment $(12.94 \%)$. Increasing the fertilizer levels led to increase pre-harvest fruit drop values in both seasons. This may be due to the importance of the nutrients ratio on nutrients storage and its reflect on tree strength. These results are in agreement with those obtained by Du-Plesis and Koen (1988) on Valencia orange trees and Malavolta (1992).

\subsection{Fruit weight (g):}

Fruit weight affected by the tree strength and the number of fruits on the tree. Data presented in Table (2) showed that, fruit weight (g) was high significantly affected by the used fertilizer. The highest fruit weight in the first season of $243.9 \mathrm{~g}$ was recorded with the farmer treatment. This may be due to this treatment had the lowest fruit set\% value and the highest pre-harvest fruit drop value $\%$.

Table 1. Some physical, chemical and nutritional properties of the experimental soil

\begin{tabular}{|c|c|c|c|c|c|c|c|c|c|c|}
\hline \multirow[t]{2}{*}{ Season } & \multicolumn{3}{|c|}{ Particle size distribution } & \multirow[t]{2}{*}{ Texture } & \multirow[t]{2}{*}{$\mathbf{p H}$} & \multirow{2}{*}{$\begin{array}{c}\text { EC } \\
\mathrm{dS} \mathbf{~ m}^{-1} \\
\end{array}$} & \multirow[t]{2}{*}{ OM\% } & \multicolumn{3}{|c|}{ Available mg/kg } \\
\hline & Sand $\%$ & Silt $\%$ & Clay \% & & & & & $\mathbf{N}$ & $\mathbf{P}$ & $\mathbf{K}$ \\
\hline $2007 / 2008$ & 23.4 & 43.9 & 32.7 & Silty clay & 7.3 & 1.25 & 1.8 & 33 & 5.9 & 230 \\
\hline $2008 / 2009$ & 23.4 & 43.9 & 32.7 & Silty clay & 7.3 & 1.32 & 1.75 & 37 & 6.5 & 245 \\
\hline
\end{tabular}

* $\mathrm{pH}$ measured in 1:2.5 soil:water suspension

$* *$ EC determined in soil past extract 


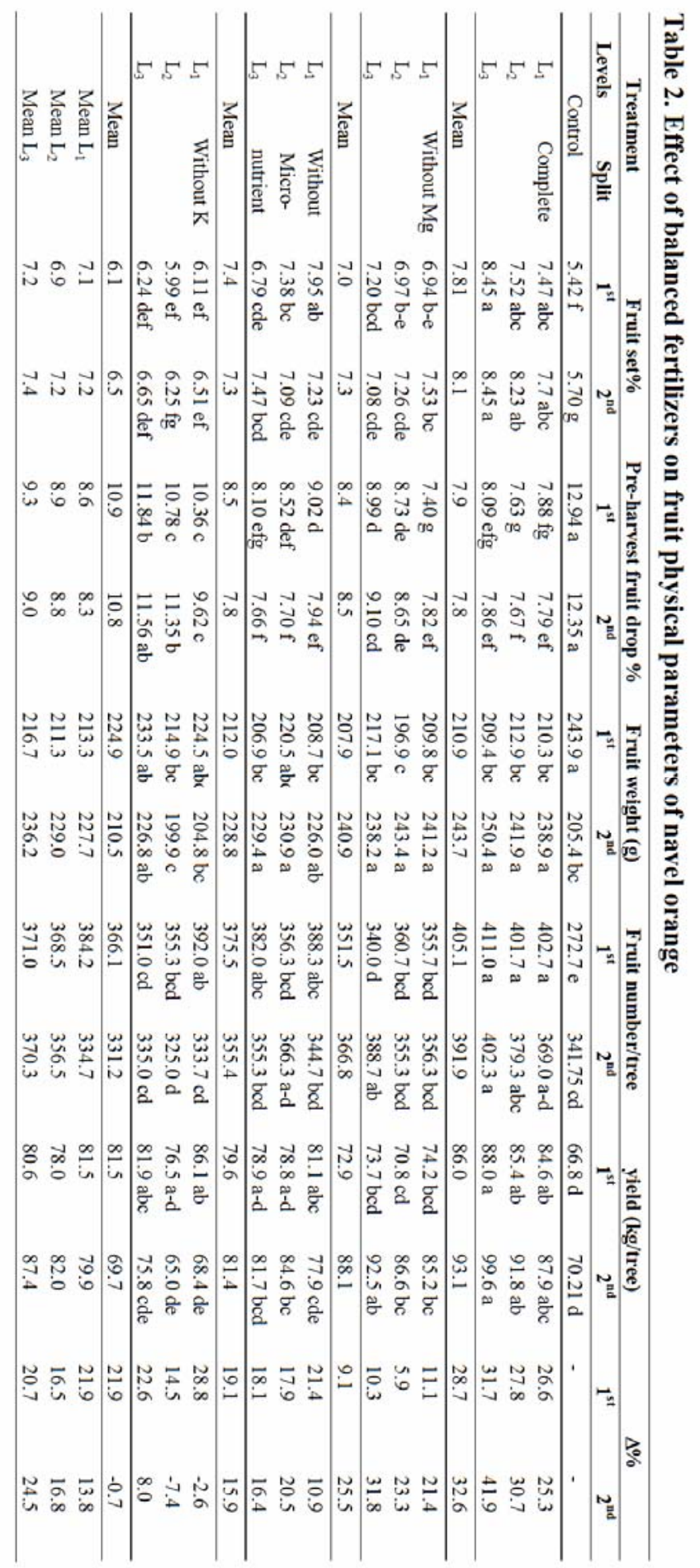


The treatment had highest fruit set $\%$ and lowest preharvest drop value showed the lowest fruit weight. In the second season, the highest fruit weight value of $250.4 \mathrm{~g}$ was obtained with the complete fertilizer. Effect of fertilizer levels on fruit weight showed that, the highest fruit weight mean values of 216.7 and $236.2 \mathrm{~g}$ were obtained with the highest fertilizer level in the first and second seasons, respectively.In respect to the interaction between fertilizer content and fertilizer levels in the second season, the highest fruit weight value of $250.4 \mathrm{~g}$ was obtained with the complete fertilizer and the highest fertilizer level (L3). This may be due to high need of citrus trees to the nutrients. Similar results were reported by Assi et al. (1990), on Balady mandarin trees Cicala and Catara (1994) on Tarracco orange trees, Erner et al. (2002) and Abd ElMigeed et al. (2007) on Washington navel orange trees.

\subsection{Fruit number/tree:}

Fruit number per tree depended on fruit set and preharvest fruit drop. Data in Table (2) cleared that the highest means fruit number of tree 405.1 and 391.9 were obtained with the complete fertilizer in the first and second seasons, respectively. In respect to the interaction between fertilizer content and fertilizer levels showed that, the highest fruit number values of 411.0 and 402.3 were observed with the complete fertilizer and the highest fertilizer level (L3) in the first and second seasons, respectively. These results are in agreement with those obtained by Swietlik (1992) on "Ray Ruby" grape fruit trees, Omran et al. (1998), Hikal (2000) and Abd El-Migeed et al. (2007) on Washington navel orange trees. This may be due to the increase in fruit set $\%$ and the decrease in pre-harvest fruit drop.

\subsection{Yield (kg/tree):}

Data in Table (2) showed that, complete fertilizer had the highest fruit yield mean values of 86.0 and 93.1 $\mathrm{kg} /$ tree in the first and second seasons, respectively. These increase rates were represent 28.7 and $32.6 \%$ over the farmer treatment in the first and second season, respectively. The interaction between fertilizer content and fertilizer levels showed that the highest fruit yield of 88.0 and $99.6 \mathrm{~kg} /$ tree were obtained with the highest fertilizer level $\left(\mathrm{L}_{3}\right)$ with the complete fertilizer in the first and second seasons, respectively. The increase rate of yield $(\mathrm{kg} /$ tree) in the other treatments was less than the complete fertilizer. It was 9.1 and $25.5 \%$ with fertilizer without magnesium and 19.1 and 15.9 with fertilizer without micronutrients in the first and second seasons, respectively. Similar results were reported by Du-Plesis and Koen (1988), Das and Barual (1997) on Assam lemon trees, Omran et al. (1998), Alva et al. (2001), Abd El-Migeed et al. (2007) and Glenn (2009) on lemon trees.

\section{The effect of balanced fertilizers on fruit chemical parameters of navel orange:}

\subsection{Soluble solids content (SSC\%):}

Data presented in Table (3) showed that, balanced fertilization and fertilizer levels significantly affected fruit chemical parameters of navel orange. Soluble solids content (SSC\%) showed clear response to fertilizer content, where the highest mean values (11.9 and 12.3\%) were obtained with the complete fertilizer in the first and second seasons, respectively. The other treatments showed a decrease in SSC\% means compared with the balanced treatment, its values were 10.7 and $10.1 \%$ with fertilizer without magnesium, 10.9 and $11.0 \%$ with fertilizer without micronutrients and 11.8 and 11.6 with fertilizer without potassium compared with 11.9 and $12.3 \%$ in farmer treatment during the first and second seasons, respectively. From the mentioned results data clear that, magnesium had rather effect on SSC\% than micronutrients and potassium. In respect, the fertilizer levels led to increase SSC\%. This may be due to the importance of magnesium and other balanced fertilizer content in photosynthesis and plant metabolism. These results agree with those obtained by Ahmed et al. (1988) on Egyptian Balady lime trees, Omran et al. (1998), Thomas (2001), Kassem and El-Sabrout (2002), El-Abd (2005) and abd El-Migeed et al. (2007) on Washington Navel orange trees.

\subsection{Acidity (\%):}

Results in Table (3) mentioned that, acidity \% is significantly affected by fertilizer content and fertilizer levels. The lowest acidity values of 0.92 and $0.91 \%$ were recorded with the farmer treatment in the first and second seasons, respectively. The highest mean values of 0.98 and $0.98 \%$ were observed with the fertilizer without magnesium. In respect to the fertilizer levels, increasing the fertilizer levels from $\mathrm{L}_{1}$ to $\mathrm{L}_{2}$ and $\mathrm{L}_{3}$ led to increase mean values of the acidity from $0.95,0.94$ to $0.96,0.95$ and $0.97,0.97 \%$ in the first and second seasons, respectively. In the same notice Marschner (1995) reported that the high concentrations of potassium in the cytosol and chloroplast neutralize the soluble and insoluble macromolecular anion and stabilizes the $\mathrm{pH}$ in these compartments. These results are in harmony with the obtained by Hikal (2000) and El-Abd (2005) on Washington Navel orange trees.

\subsection{Vitamin $C$ content:}

Citrus has a great nutritional role in our daily food requirements being a rich source of vitamin C. Data in Table (3) observed that vitamin $\mathrm{C}$ is significantly affected by fertilizer contents and fertilizer levels. 


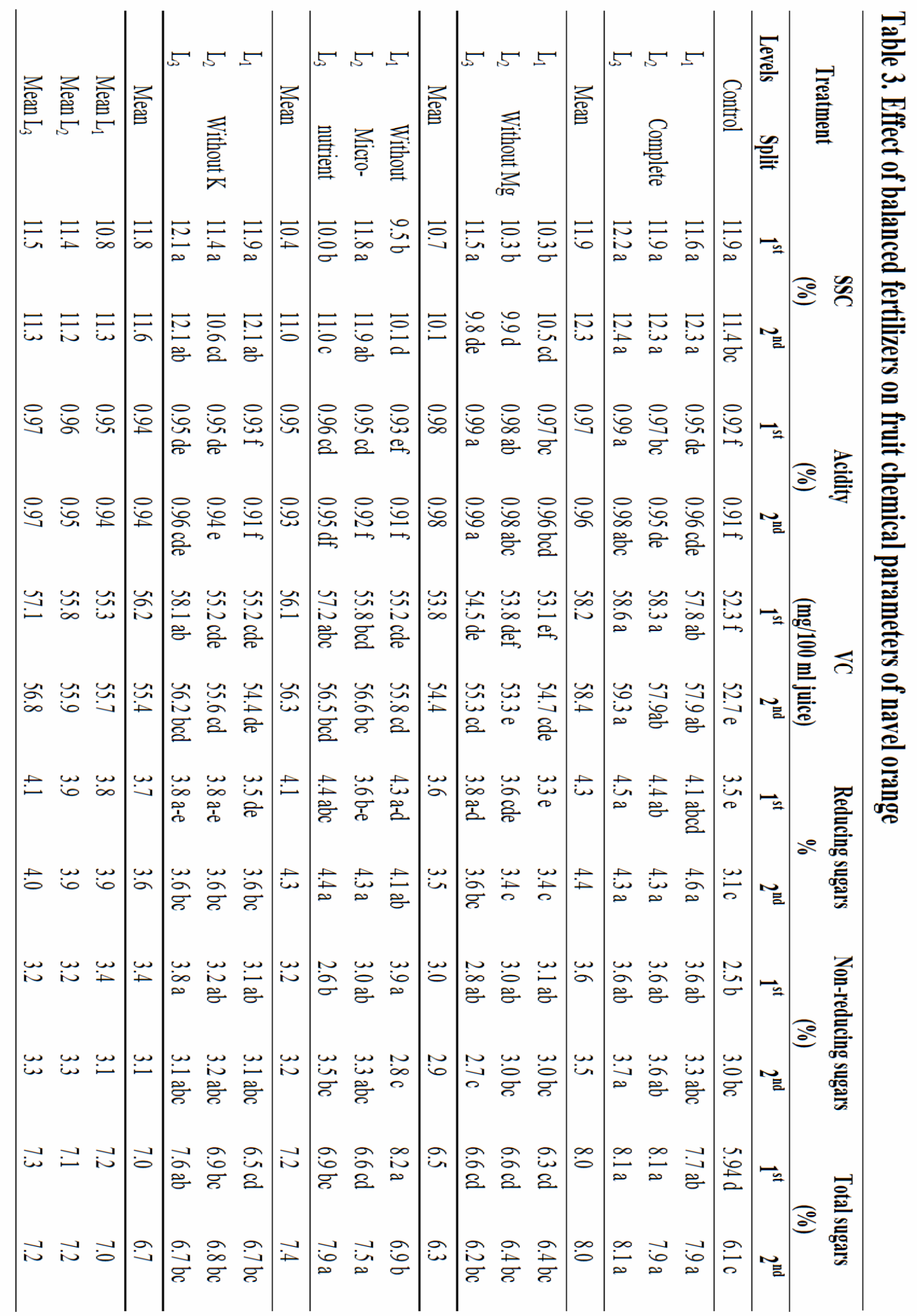


Complete fertilizer (balanced fertilizer) increased VC from 52.3 and $52.7 \mathrm{mg} / 100 \mathrm{ml}$ juice (farmer treatment) to 58.2 and $58.4 \mathrm{mg} / 100 \mathrm{ml}$ juice represent $11.3 \%$ and $10.8 \%$ increase in the first and second seasons, respectively compared with farmer treatment. Fertilizer without magnesium led to increase rate of $\mathrm{VC}$ over the farmer treatment by 2.9 and $3.2 \%$ in the first and second seasons, respectively, but it was less than the complete fertilizer by 8.4 and $7.6 \%$ in the first and second seasons, respectively. Fertilizer without micronutrients increased VC over the farmer treatment by 7.3 and $6.8 \%$ in the first and second seasons, respectively, but it was less than the complete fertilizer by $4.0 \%$ in both seasons. Fertilizer without potassium increased VC over the farmer treatment by 7.5 and $5.1 \%$ in the first and second seasons, respectively, but it was less than the complete fertilizer by 3.8 and $5.7 \%$ in the first and second seasons, respectively. In respect to increasing the fertilizer levels from $\mathrm{L}_{1}$ to $\mathrm{L}_{2}$ and $\mathrm{L}_{3}$ led to increase the mean values of $\mathrm{VC}$ from 55.3, 55.7 to $55.8,55.9$ and $57.1,56.8 \mathrm{mg} / 100 \mathrm{ml}$ juice, represent increase 0.9 , $0.4 \%$ with $\mathrm{L}_{2}$ and $3.3,2.0 \%$ with $\mathrm{L}_{3}$ in the first and second seasons, respectively. The interaction between fertilizer content and fertilizer levels showed that, the highest VC values of 58.6 and $59.3 \mathrm{mg} / 100 \mathrm{ml}$ juice were obtained with the highest fertilizer level $\left(\mathrm{L}_{3}\right)$ and the complete fertilizer (balanced). This may be due to that each macro- or micronutrient had different role on the quality of citrus fruits. These results are in agreement with those obtained by Tariq et al. (2007) on Sweet orange trees, who concluded that, $\mathrm{VC}$ was increased significantly by the application of $\mathrm{Zn}+\mathrm{B}$ through foliar spray. Similar results were obtained by Hikal (2000), Mostafa (2002), El-Abd (2005) and Abd El-Migeed et al. (2007) on Washington navel orange.

\subsection{Sugar contents (\%)}

Reducing, non reducing and total sugars \% are significantly affected by the used fertilizers as recorded in Table (3). All the used fertilizers increased reducing, non-reducing, and total sugars \% comparing to the farmer treatment. The increase rates in the reducing sugars over the farmer treatment were $(22.8,41.9 \%)$, $(2.9,12.9 \%),(17.1,38.7 \%)$ and $(5.7,16.1 \%)$ with the complete fertilizer, fertilizer without $\mathrm{Mg}$, fertilizer without micronutrients and fertilizer without $\mathrm{K}$ in the first and second seasons, respectively. The increase rates in the non-reducing sugars over the farmer treatment were $(44.0,16.7 \%),(20.0$, zero $\%),(28.0$, $6.7 \%)$ and $(36.0,3.3 \%)$ with complete fertilizer, fertility without $\mathrm{Mg}$, fertility without micronutrients and fertility without $\mathrm{K}$ in the first and second seasons, respectively. In the total sugars $\%$, the increase rates over the farmer treatment were $(34.7,31.1 \%),(9.4,3.3 \%),(21.2$, $21.3 \%)$ and $(17.8,9.8 \%)$ with the complete fertilizer, fertilizer without $\mathrm{Mg}$, fertilizer without micronutrients and fertilizer without $\mathrm{K}$ in the first and second seasons, respectively. No clear trend was observed with the fertilizer levels on the reducing, non-reducing and total sugars $\%$. The obtained results are in harmony with those obtained by Kassem and El-Sabrout (2002), ElAbd (2005) on Washington Navel orange trees and Tariq et al. (2007) on Sweet orange trees who reported that, reducing sugars \% was significantly affected by the used elements like Mn.

\section{The effect of balanced fertilizers on chlorophyll A, $B$ and total chlorophyll $\mu \mathrm{g} / \mathrm{cm}^{2}$}

Data presented in Table (4) showed that, balanced fertilizer (complete fertilizer) significantly increased chlorophyll A compared to farmer treatment from 61.6 and $68.8 \mu \mathrm{g} / \mathrm{cm}^{2}$ to 92.0 and $99.4 \mu \mathrm{g} / \mathrm{cm}^{2}$ in the first and second seasons, respectively. The increases in chlorophyll B was from 48.0 and $51.6 \mu \mathrm{g} / \mathrm{cm}^{2}$ to 67.7 and $74.0 \mu \mathrm{g} / \mathrm{cm}^{2}$ in the first and second seasons, respectively. While, the increase in total chlorophyll was from 109.6 and 120.5 to 159.7 and $173.5 \mu \mathrm{g} / \mathrm{cm}_{2}$ represent increase rates of 45.8 and $44.0 \%$ over the farmer treatment in the first and second seasons, respectively.

The other treatments increased both of chlorophyll $\mathrm{A}, \mathrm{B}$ and total chlorophyll fertilizer without $\mathrm{Mg}$ increased Chl.A to 79.1 and $88.8 \mu \mathrm{g} / \mathrm{cm}^{2}$, chl.B to 57.5 and $65.1 \mu \mathrm{g} / \mathrm{cm}^{2}$ and total chl. to 153.3 and 155.0 $\mu \mathrm{g} / \mathrm{cm}^{2}$ compared to the farmer treatment in the first and second seasons, respectively. The increased rates compared with the control were 39.9 and $28.6 \%$ during the two seasons, respectively

These values with fertilizer without micronutrient were 70.2 and $81.0 \mu \mathrm{g} / \mathrm{cm}^{2}$ in chl.A, 51.9 and 60.0 $\mu \mathrm{g} / \mathrm{cm}^{2}$ in chl. B. and 122.00 and $141.1 \mu \mathrm{g} / \mathrm{cm}^{2}$ in total chl. compared with the farmer treatments in the two seasons, respectively. While treatment without $\mathrm{K}$ increased it to 87.4 and $95.0 \mu \mathrm{g} / \mathrm{cm}^{2}$ in chl.A, 64.7 and $70.3 \mu \mathrm{g} / \mathrm{cm}^{2}$ in chl.B and 152.1 and $165.4 \mu \mathrm{g} / \mathrm{cm}^{2}$ in total chl. in the two seasons, respectively. The increase rates of the two treatments compared with the control were $11.3,17.1 \%$ and $38.8,37.3 \%$ during the two seasons, respectively.

In respect the fertilizer levels increased chlorophyll A, B and total chlorophyll in both seasons, $\mathrm{L}_{1}$ increased total chlorophyll by 26.0 and $28.0 \%$ over the farmer treatment. $\mathrm{L}_{2}$ increased total chlorophyll by 29.9 and $32 \%$, while $\mathrm{L}_{3}$ increased total chlorophyll by 41.9 and $35.3 \%$ in the first and second seasons, respectively. These results are in agreement with those obtained by Du-Plesis and Koen (1988) on Valencia orange trees, 


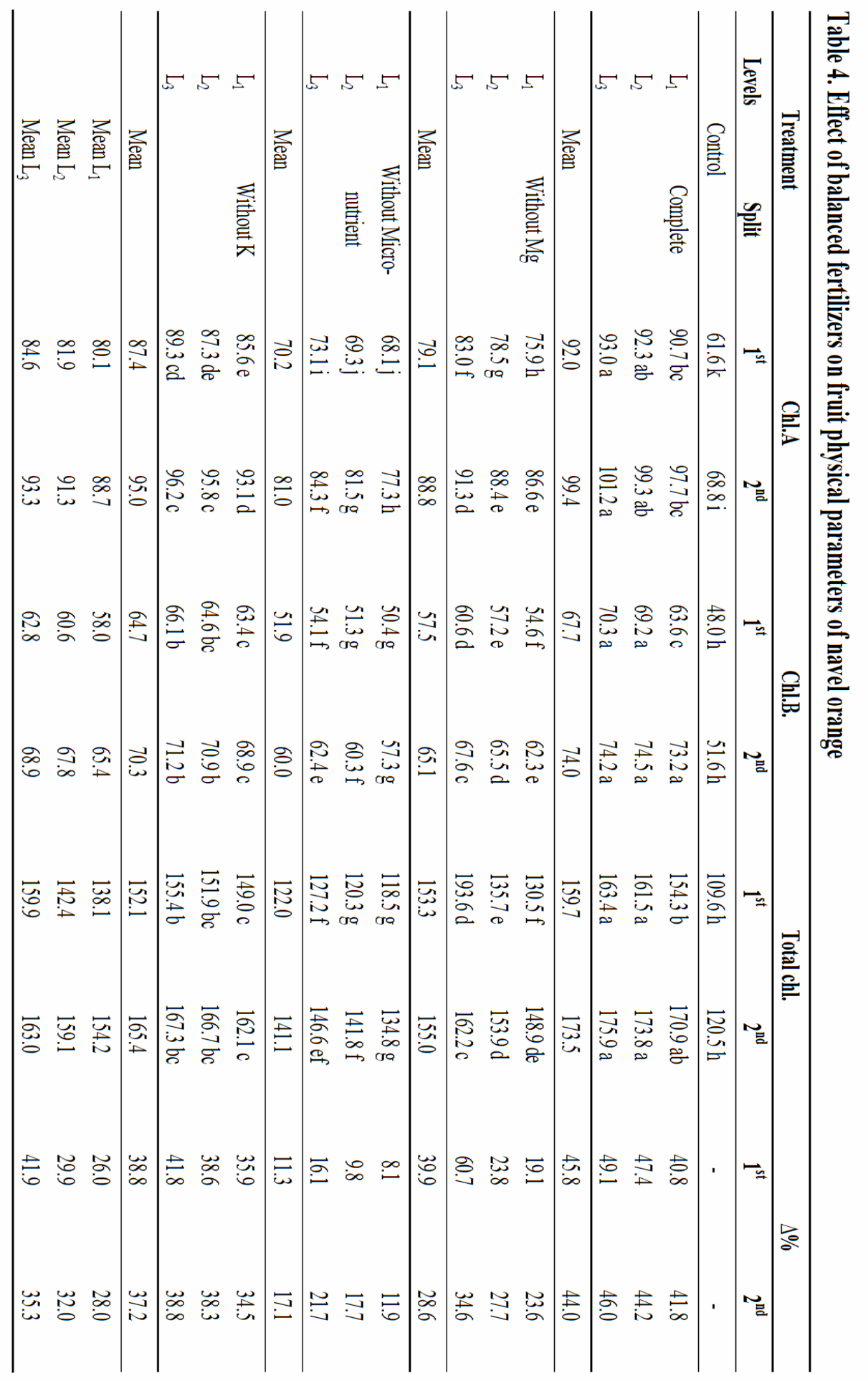


Malavolta (1992), El-Sabrout and Kassem (2002), ElAbd (2005), Glenn (2009) on lemon trees, Muhammed Yaseen and Manzoor Ahmad (2010) on Sweet orange trees and Muhammad et al. (2010).

\section{CONCLUSION}

From the previous data, it could be concluded that the balanced fertilizers $(\mathrm{N}+\mathrm{P}+\mathrm{K}+\mathrm{Mg}+$ micronutrients $)$ are the best tool to improve navel orange growth, fruit set $\%$, fruit number/tree and maximum yield, it increased fruit yield by $32.6 \%$ over the farmer fertilization treatment and improved fruit quality, it increased $\mathrm{SSC} \%$, VC (mg/100 ml juice), reducing, non-reducing and total sugars.

Potassium deficiency in the fertilization had the lowest effect on increasing fruit yield and quality followed by the micronutrietns deficiency and followed by magnesium deficiency compared with the balanced fertilizers during the two seasons, respectively.

Balanced fertilizers increased fertilizer efficiency under the low, medium and high fertilizer levels compared with the other treatments and the control under the three levels during the two seasons, respectively.

\section{REFERENCES}

Abd El-Migeed, M.M.N.; Saleh, M.M.S. and E.A. Mostafa (2007). The beneficial effect of minimizing mineral nitrogen fertilization on Washington navel orange trees by using organic and biofertilizers. World Journal of Agricultural Science, 3(1): 80-88.

Ahmed, F.F.; M.A. El-Sayed and M.A. Maatouk (1998). Effect of nitrogen, potassium and phosphorus fertilization on yield and quality of Egyptian Balady lime trees (Citrus aurantifolia). 2- Yield and fruit quality. Annals Agric. Sci., Fac. Agric., Ain Shams Univ., Cairo, Egypt, 33(1): 1244-1268.

Alva, A.K.; S. Paramasivam and K.H. Hostler (2001). Effect of nitrogen rates on dry matter and nitrogen accumulation in citrus fruits and fruit yield. J. Plant Nutri., 24(3): 561572.

A.O.A.C. (Association of Official Agriculture Chemist) (1985). Official methods of analysis. Washington D.C. $10^{\text {th }}$.

Assi, K.G.; F.F. Ahmed; M.H. Rabie and A.O. Osman (1990). A comparative study on the effect of foliar and soil application of potassium to Balady mandarin trees (Citrus reticulate Blanco). Agricultural Research Review, 68(2): 321-329.

Beanland, L.; P.L. Phelam, and S. Salminen, (2003). Micronutrient interaction on soybean growth and the developmental performance of three insect herbivores. Environ. Entomol., 32: 641-651.

Black, C.A.; D.D. Evans; J.L. White; L.E. Ensuminger and F.E. Clark (1965). Method of Soil Analysis. Am. Soc. Agron. Inc. Publisher. Madison, Wisconsin, USA.
Cicala, A. and V. Catara (1994). Potassium fertilization effect on yield, fruit quality and mineral composition of leaves of "Tarracco" orange trees. International Society of Citriculture, 610-620.

Das, R.K. and G.K.S. Baruah (1997). Response of young assam lemon [Citrus limon (L.) Burm.] to nitrogen in Hill zone of Assan. Horticultural Journal 10(2): 79-83.

Direcenmattos Jr.; Danilo R. Yamane; R. Rodrigo M. Boaretto; Fernando C.B. Zambrosi and Jose A. Quaggio (2010). Root development of young citrus trees in soils fertilized with phosphorus. $19^{\text {th }}$ World Congress of Soil Sci. Soil Solutions for Changing World 1-6 August 2010. Brisbane, Australia Proc., pp. 197-203.

Du-Plesis, S.F. and T.J. Koen (1988). The effect of N and K fertilization on yield and fruit size of Valencia. Proceeding of the International Soci. of Citriculture, 2: 663-672.

El-Abd, A.A. (2005). Influence of fertilization and irrigation on Washington navel orange orchards. Ph.D. Thesis, Fac. Agric., Kafr El-Sheikh, Tanta Univ., Egypt.

El-Sabrout, M.B. and H.A. Kassen (2002). 1. Effect of fertilization with nitrogen and potassium on vegetative growth, yield and leaf mineral content of "Washington" navel orange trees grown in sandy soil. J. Adv. Agric. Res., 7(3): 539-553.

Embleton, T.W.; W.W. Jones; C.K. Labanauskas and W. Reuther (1973). Leaf analysis as a diagnostic tool and guide to fertilization. In the Citrus Industry of California. Division of Agric. Sci, USA, pp. 83-210.

Erner, Y.; B. Artzi; E. Tagari and M. Hamou (2002). Potassium affects citrus tree performance. The Volacni Center, Institute of Horticulture, Department of Fruit Trees Report pp. 405-413.

Glenn, C. Wright (2009). Evaluation of nitrogen fertilization practices for surface irrigated lemon trees. Final report for project (2008-04) Dep. of Plant Sci. Univ. Ariz. Yuma Agric. Center, Yuma.

Hikal, A.R. (2000). Physiological studies on nutrition of Washington navel orange trees. Ph.D. Thesis, Fac. Agric., Mansoura Univ., Egypt.

Kassem, H.A. and M.B. El-Sabrout (2002). II. Effect of fertilization with nitrogen and potassium on fruit quality and storability of "Washington: Navel orange trees grown in sandy soils. J. Adv. Agric. Res.. Vol. 7(3): 552-569.

Malavolta, E. (1992). Leaf analysis in Brazil-present and perspectives. Processing of the Inernational Soc. of Citriculture. 2: 570-574.

Marschner, H. (1995). Mineral nutrition of higher plants. Second edition. Academic Press. London, UK.

Moran, R. and D. Porath (1982). Chlorophyll determination in intact tissues using $\mathrm{N}, \mathrm{N}$-dimethyl formamide $\mathrm{P}_{1}$ physiol. 69: $1370-1381$.

Mostafa, M.H. (2002). Studies on fertilization of Washington navel orange trees. Ph.D. Dissertatio, Fac. Agric., Moshtohor, Zagazig University, Benha branch, Egypt. 
Muhammad Sajid; Abdur-Rab; Nawab Ali; Muhammad Arif; Louise Ferguson and Masood Ahmed (2010). Effect of foliar application of $\mathrm{Zn}$ and $\mathrm{B}$ on fruit production and physiological disorders in sweet orange cv. Blood orange. Sarhad J. Agric. Vol. 26, No. 3.

Muhammad Yassen and Manzoor Ahmad (2010). Nutrition management in citrus: Effect of multinutrients foliar feeding on the yield of kinnow at different locations. Pak. J. Bot., 42(3): 1863-1870.

Omran, M.S.; B.Y. El-Koumy and L.M. Shokar (1998). Effect of organic and inorganic fertilizers on Navel orange yield (quantity and quality). Zagazig J. Agric. Res., 25(1): 163174.

Quaggio, J.A.; Cantarella, H. and Raij B. Van (2002). Phosphorus and potassium soil test and nitrogen leaf analysis as a base for citrus fertilization. Nutrient Cycling in Agroecosystem, 52: 67-74.
Sanchez, C.A.; G.C. Wright and M. Perlta (2002). Continued evaluation of $\mathrm{N}$ fertilization practices for surface irrigated lemons. Citrus and deciduous fruit and nut research report. Univ. of Arizona Cooperative Extension Publication, No. AZ 1331.

Swietlik, D. (1992). Yield, growth and mineral nutrition of young "Ray Ruby" grape fruit trees under trickle or flood irrigation and various nitrogen rates. J. Amer. Soc. Hort. Sci., 117(1): 22-27.

Tariq, M.; M. Sharif; Z. Shah and R. Khan (2007). Effect of foliar application of micronutrients on the yield and quality of sweet orange (Citrus sinensis L.). Pakistan Journal of Biological Science, 10(11): 1823-1828.

Thomas, A. Obereza (2001). Managing phosphorus fertilization of citrus using soil testing. Florida Cooperative Extension Service, Institute of Food and agric. Sci. Univ. of Florida Sl. 186: 1-6.

\section{प]}

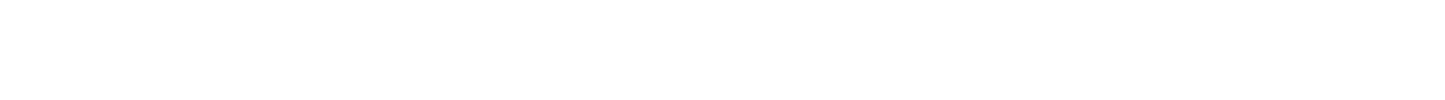

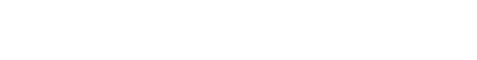

(الأل

والثإعلى التوالـ.

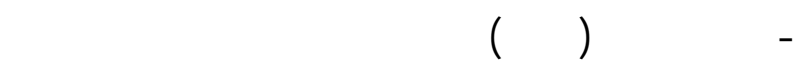

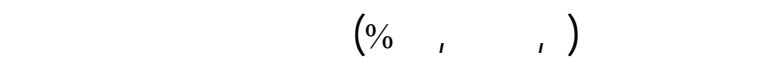

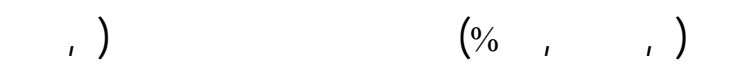

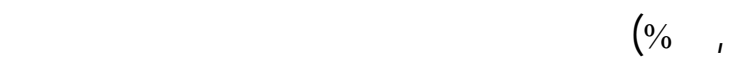
على التوال.

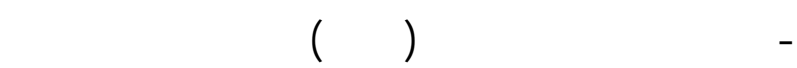

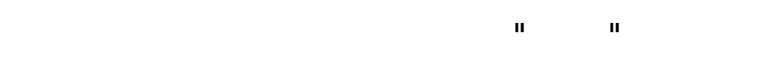

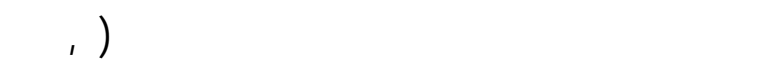

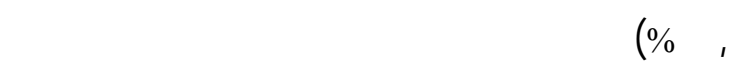

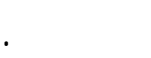

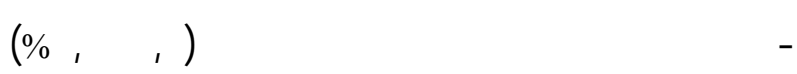

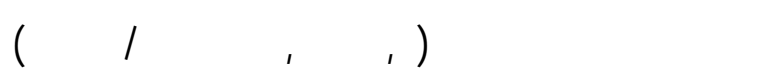

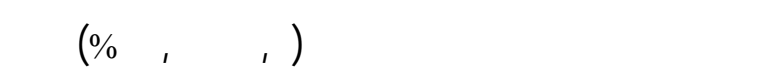

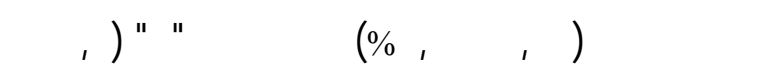

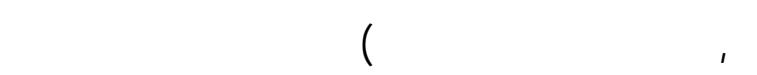

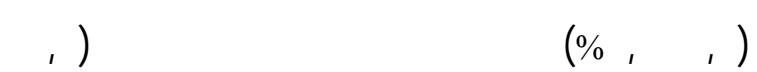

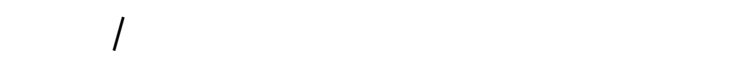

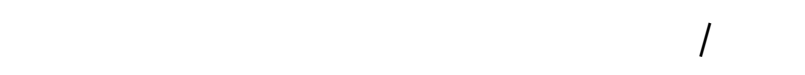

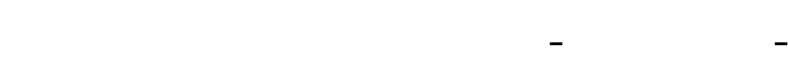
على إنتاجية الآثقل أبوسره وجوةلَاره. ذلك لأربع مع لملات ألمة:

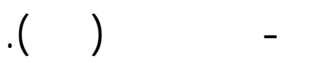

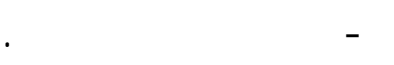

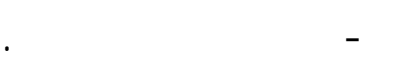

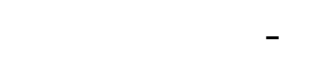

وذلك مع ثلاث مستويت من كل مذ ها تصلة المارع.

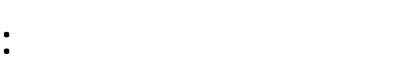

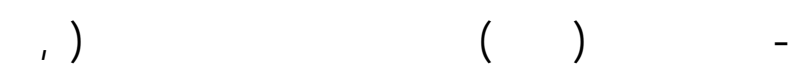

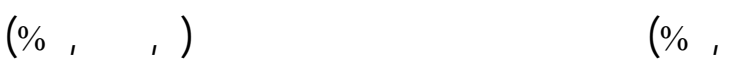

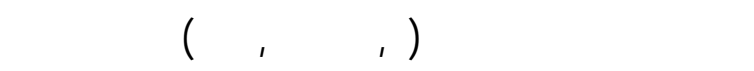

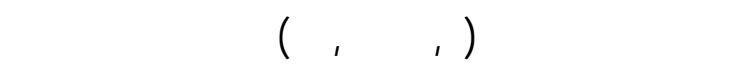

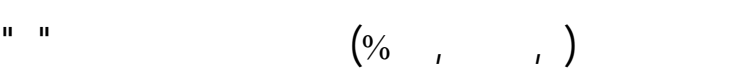




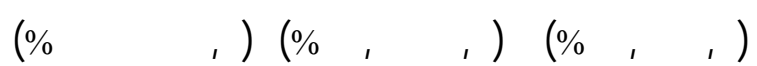
ونسة إلموض

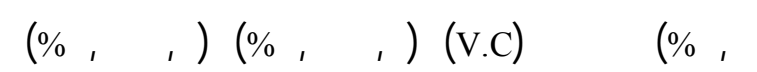

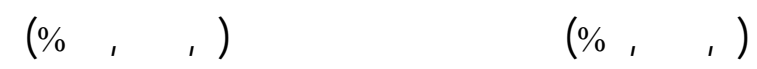

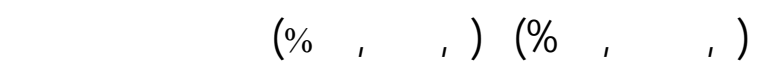

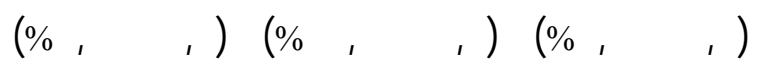

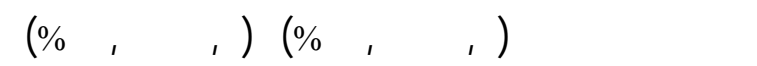
( ) الثلاة على التوالـ.

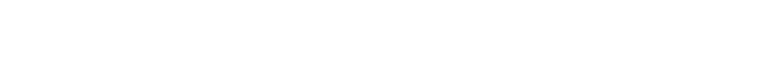

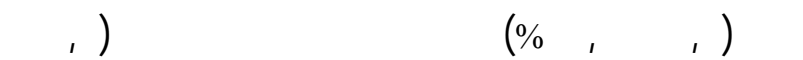

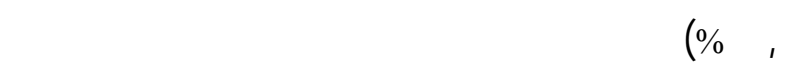
النوالـ.
كأ.

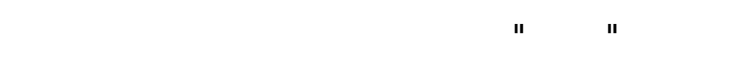
على التوالـ.

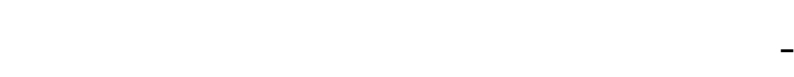

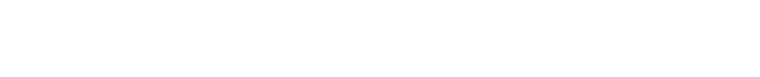

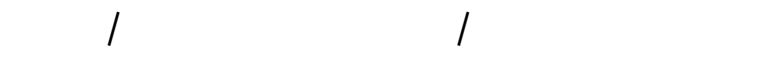

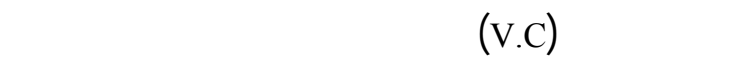

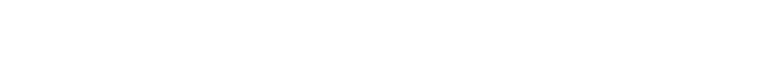

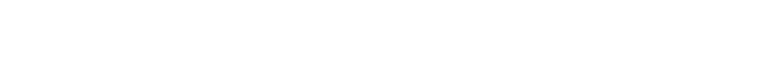
والثإ] على النوالـ.

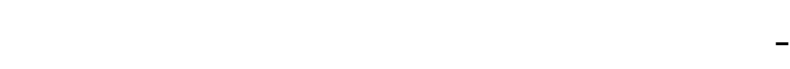

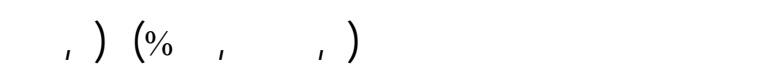

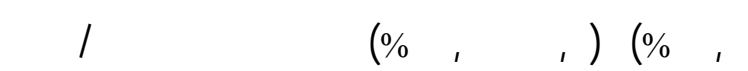

